\title{
The Role of Cell-Penetrating Peptide and Transferrin on Enhanced Delivery of Drug to Brain
}

\author{
Gitanjali Sharma ${ }^{1}$, Sushant Lakkadwala ${ }^{1}$, Amit Modgil ${ }^{2}$ and Jagdish Singh ${ }^{1, *}$ \\ 1 Department of Pharmaceutical Sciences, College of Health Professions, North Dakota State University, \\ Fargo, ND 58105, USA; gitanjali.sharma@ndsu.edu (G.S.); sushant.lakkadwala@ndsu.edu (S.L.) \\ 2 Department of Neuroscience, Tufts University School of Medicine, 136 Harrison avenue, Boston, MA 02111, \\ USA; amit.modgil@tufts.edu \\ * Correspondence: jagdish.singh@ndsu.edu; Tel.: +1-701-231-7943; Fax: +1-701-231-8333
}

Academic Editor: Buddhadev Layek

Received: 1 April 2016; Accepted: 13 May 2016; Published: 25 May 2016

\begin{abstract}
The challenge of effectively delivering therapeutic agents to brain has led to an entire field of active research devoted to overcome the blood brain barrier (BBB) and efficiently deliver drugs to brain. This review focusses on exploring the facets of a novel platform designed for the delivery of drugs to brain. The platform was constructed based on the hypothesis that a combination of receptor-targeting agent, like transferrin protein, and a cell-penetrating peptide (CPP) will enhance the delivery of associated therapeutic cargo across the BBB. The combination of these two agents in a delivery vehicle has shown significantly improved $(p<0.05)$ translocation of small molecules and genes into brain as compared to the vehicle with only receptor-targeting agents. The comprehensive details of the uptake mechanisms and properties of various CPPs are illustrated here. The application of this technology, in conjunction with nanotechnology, can potentially open new horizons for the treatment of central nervous system disorders.
\end{abstract}

Keywords: cell-penetrating peptide (CPPs); transferrin; blood brain barrier (BBB); liposomes; functionalization

\section{Introduction}

Over recent years, there has been a considerable progress in the field of neuroscience leading to an improved understanding of disorders of the central nervous system (CNS). In contrast, the development of successful strategies for treating these disorders is limited due to the protective function of the blood brain barrier (BBB). The concept of the BBB originated in late 19th and early 20th centuries, when Paul Ehrlich and his colleagues discovered that some dyes could stain the brain cells after direct injection into brain, but were not able to penetrate brain after peripheral administration [1]. A parallel study revealed that bile salts induced seizures after direct injection into brain, but did not show any related symptoms after peripheral administration [2,3]. Since then, there have been comprehensive efforts to provide a scientific definition of BBB and to elucidate the mechanisms of the transport of different molecules across this barrier [4-7]. More restrictively, BBB is defined as the microvasculature of brain that is composed of endothelial cells having tight intracellular junctions and the absence of any fenestrae [4].

However, the vascular BBB does not explain all facets of conceptual BBB. The choroid plexus with cerebrospinal fluid, referred to as the cerebrospinal fluid barrier (CSFB), is another important gateway to reach brain parenchyma [8,9]. The entry of any molecule into brain, after parenteral administration, is largely controlled by BBB and CSFB [7]. However, the CSFB faces a ventricle that flushes the drug, injected in the back of the ventricle, back into the blood [10,11]. Moreover, there are about 100 billion capillaries with a surface area of $20 \mathrm{~m}^{2}$ that contribute to the formation of BBB [12]. 
Therefore, BBB is universally considered the most important barrier in restricting the transport of molecules into brain [13]. There has been an increasing incidence of the use of cell-penetrating peptides (CPPs) in the transport of therapeutic molecules into brain. CPPs are short cationic peptides (less than 30 amino acids) that have the ability to transport extracellular molecular cargo into the cells. These peptides are capable of entering the cells without producing cytolytic effects. In addition, they effectively bypass P-glycoprotein (P-gp) in the BBB and are therefore used as vectors for the delivery of drugs that are substrates for P-gp [14]. The CPPs are primarily considered to be transported via energy-dependent pathways, but the exact mechanism is not yet fully understood. While for some CPPs, endocytosis is the exclusive mechanism of uptake, for others, it is an alternative mechanism [15]. The use of CPPs is based on the fact that these peptides can be linked to the therapeutically-active molecules and can be transported across the cell membrane. This linkage can either be covalent or non-covalent. Various cargo molecules and delivery agents have been delivered into the cells using CPPs, e.g., proteins, small drug molecules, nucleic acids, liposomes and nanoparticles. The major challenge of using CPPs as transporters of therapeutic molecules is their non-targeting disposition. The combination of these CPPs with receptor- or protein-targeting moieties can actively deliver the molecules of interest into desired cells in sufficient concentrations [16-18].

\section{Role of the Blood Brain Barrier in Reducing the Penetration of Molecules into Brain}

The high impermeability and selectivity of the blood brain barrier prevents the transport of many drugs and other therapeutic molecules into brain $[19,20]$. The delivery of therapeutic agents across BBB has engendered substantial interest over the past few decades $[9,21,22]$. BBB possesses unique biological characteristics that contribute to restricting the movement of molecules to brain (Figure 1):

(1) Brain endothelial cells lack fenestrations, have very few pinocytotic vesicles and a larger number of mitochondria [23-25].

(2) The occurrence of an intricate complex of transmembrane proteins (e.g., occludins, claudins), forming intimate intracellular connections, called tight junctions (TJ).

(3) The expression of different transport proteins on brain endothelial cells, like $p$-glycoproteins (efflux transporters) and multidrug resistance proteins (MRPs) [10,26].

(4) The synergistic influence of astrocytes, pericytes, astrocytic perivascular end feet, macrophages and neurons on BBB functions [27-29].

The immune barrier of brain is formed by tightly-packed endothelial cells, perivascular macrophages and mast cells and is further reinforced by the macroglial cells. This barrier limits the passage of external immune cells, especially lymphocytes, across BBB [30-34].

This unique environment of CNS presents a formidable barrier to the delivery of a wide number of therapeutic molecules to brain. With the exception of small lipophilic drug molecules having a molecular mass of less than 400-600 Da, most of the drugs in circulation do not penetrate the BBB $[34,35]$. More than $98 \%$ percent of the drugs are halted mid-development due to poor brain permeability [36]. Furthermore, recent statistics from the National Cancer Institute show about 22,910 new cases of brain tumor leading to 13,700 deaths, each year. In addition, neuro-degenerative diseases like Alzheimer's disease have become the most common cause of dementia among the elderly and have been reported to affect about $5 \%$ of Americans over the age of 65 and $20 \%$ over the age of 80 years [37]. These factors have triggered extensive efforts, by scientists across the globe, in developing safe and efficient vectors for the delivery of therapeutics to brain. Viruses are equipped with different molecular mechanisms to overcome these hurdles and can, therefore, serve as efficient delivery vectors [38]. Yet, the potential application of viruses as delivery agents and their further investigation in clinical research is impeded by the associated immune response and cytotoxicity, thereby accentuating the need for the synthesis of safe and efficient non-viral delivery vectors. Multidisciplinary approaches involving biology, nanotechnology and biophysics need to be considered to accomplish the goal of improving the delivery of therapeutic drugs and genes across BBB [7]. 


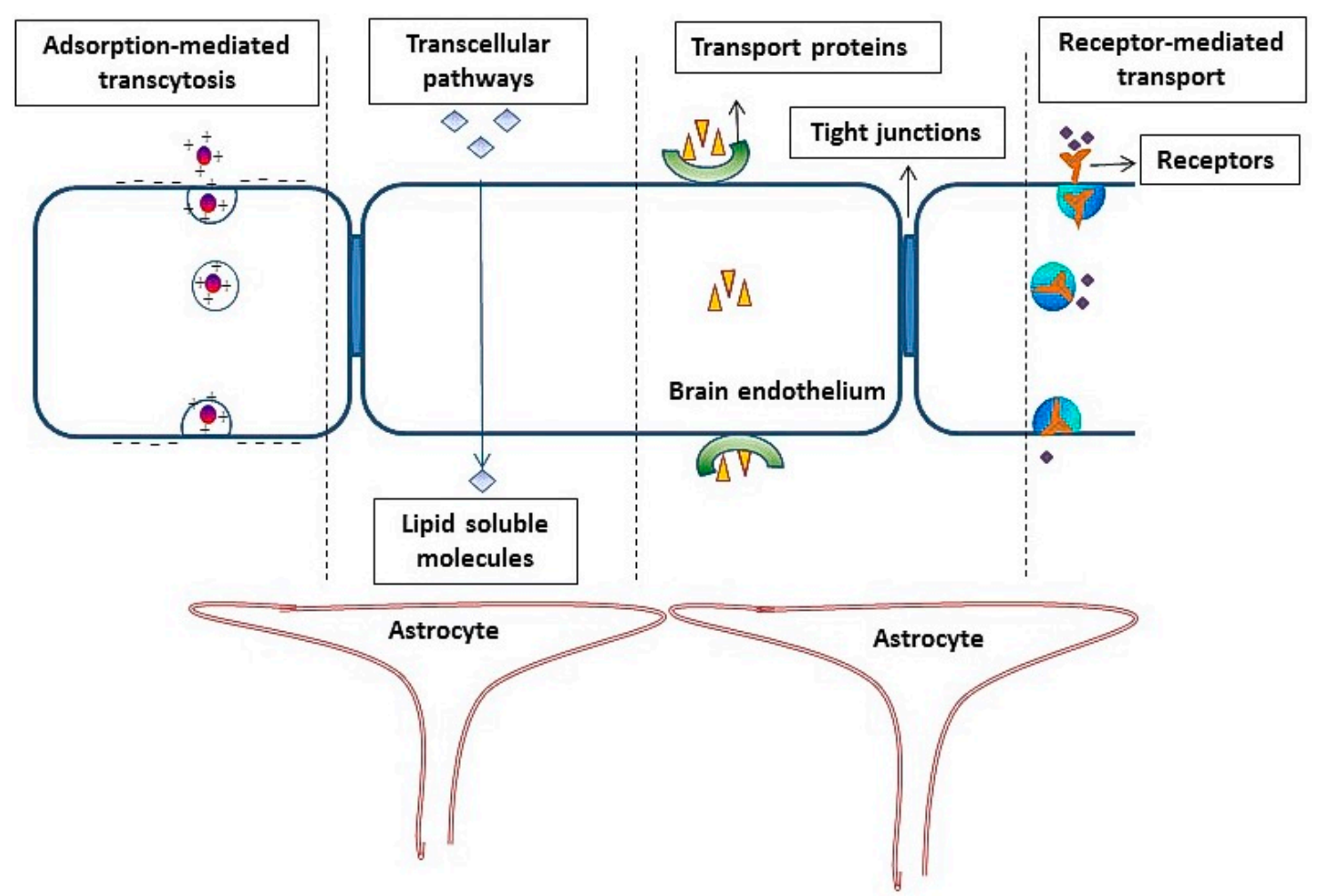

Figure 1. Schematic representation of the blood brain barrier and various transport processes across the brain endothelial layer.

Certain inflammatory conditions of brain, for example Alzheimer's disease, multiple sclerosis, tumors and stroke, have been known to increase the permeability of BBB. Various inflammatory mediators associated with these CNS disorders can modulate the tight junctions and enhance the passage of molecules across brain endothelium. Apart from the modulation of tight junctions on the endothelium, other closely-associated cells, such as pericytes, astrocytes, mast cells, glial cells and neurons, are also reported to be involved in inflammatory reactions [39]. Many inflammatory agents, like bradykinin, serotonin and histamine, increase leakage across blood brain barrier by increasing both endothelial permeability and vessel diameter, thereby causing cerebral edema.

Lopez-Ramirez et al. [40] recently reported that a molecule called "microRNA-155" is responsible for cleaving epithelial and endothelial cells. This cleavage can create microscopic gaps in the endothelium, leading to increased permeability of BBB. This discovery has opened a completely new platform for developing therapies that can help penetrate the BBB and deliver potential agents for the treatment of CNS disorders [40].

\section{Cell-Penetrating Peptides}

Cell-penetrating peptides (CPPs) are short cationic or amphipathic peptides that have the ability to transport the associated molecular cargo (e.g., peptides, proteins, oligonucleotides, liposomes, nanoparticles, bacteriophages, etc.) inside the cells [16]. Biological evolution has conferred certain proteins with an ability to penetrate the cell membrane due to the presence of specific peptide sequences, called protein transduction domains [41]. The peptide sequences constituting these domains carry basic amino acids and possess cell-penetrating properties; thus, these peptides are referred to as cell-penetrating peptides (CPPs). Over the past decade, there has been a vibrant increase in the application of these CPPs for the delivery of cargo molecules inside the cells [42]. These peptide sequences have been utilized for the delivery of various molecules, like proteins, nucleic acids, liposomes and nanoparticles, across the cell membrane [43-47]. The profound interest evoked by the 
CPPs among scientists is not only attributed to their ability of crossing the cell membrane via receptor and energy-independent processes, but also their capacity to efficiently internalize the associated biomolecules without compromising their biocompatibility [48]. Various CPPs, such as poly-L-arginine (PR), transactivator of transcription peptide (TAT) [49] and penetratin, have been conjugated to the delivery vectors to improve the delivery of therapeutic molecules [50-52].

\subsection{Poly-L-Arginine}

Polyarginine is a synthetic cationic peptide consisting of eight or more arginine residues and has been used to facilitate the intracellular translocation of a wide variety of molecular cargo [16,17]. This cell-penetrating peptide has been used for the delivery of cargo, such as liposomes, nucleic acids, nanoparticles, etc., into the cells. Kibria et al. [50] showed that dual modification of liposomes with polyarginine and cyclic RGD (Arg-Gly-Asp) peptide significantly increased the transfection efficiency of liposomes in integrin $\alpha(v) \beta(3)$-expressing cells. Later, Opanasopit et al. [53] demonstrated considerable improvement in the transfection efficiency of liposomes after coating with poly-L-arginine. A previous report provided a deeper insight into the interaction of cationic peptides with the phospholipid bilayer during the surface adsorption of positively-charged amino acids onto the liposomal surface [54]. The results showed that the adsorption of cationic amino acids, like arginine, was not only driven by electrostatic interactions, but also by polarization forces and caused surface rearrangements in the phospholipid membrane. Zhang et al. [55] showed that siRNA-containing octaarginine-modified liposomes efficiently inhibited the targeted gene and significantly reduced the tumor cell proliferation.

\subsection{HIV-1 Trans-Activator of Transcription Peptide}

TAT is a protein encoded by the TAT gene of HIV-1. TAT was discovered with the emergence of various CPPs of natural (AntP/penetratin) and synthetic (mastoparan/transportan) origin that have been alternatively termed as protein transduction domains (PTDs) [56,57]. Over recent years, TAT peptide has gained significant attention in the field of nucleic acids and drug delivery. A previous study compared the transfection efficiencies of the SLN gene delivery vector and polyethylenimine (PEI), in vitro and in vivo. The presence of TAT significantly enhanced the gene expression of SLNs in different cell lines as compared to the PEI nanoparticles [58]. Another group of scientists reported efficient gene delivery using TAT peptide-functionalized polymeric nanoparticle complexes into undifferentiated and differentiated SH-SY5Y cells [59]. TAT peptide-modified liposomes showed considerable improvement in the delivery of plasmid-encoding green fluorescent protein (pGFP) to human brain tumor U-87 cells in vitro and in an intracranial tumor mice model [60]. TAT-modified liposomes synthesized with small quantities of the cationic lipid, dioleoyl trimethylammonium propane (DOTAP) showed substantially higher gene expression levels in mouse fibroblast NIH3T3 and cardiac myocyte H9C2 cells and lower cytotoxic potential as compared to the commercially available transfecting reagent Lipofectin ${ }^{\circledR}[45,61]$. Despite the large area of application of the TAT peptide, the exact mechanism of its cellular internalization still appears controversial. Variable results illustrating different mechanisms of uptake can result from variation in different experimental factors, like the wide range of the sequences of TAT peptide used, variable cell lines and different protocols for the investigation of the mechanism of entry, which can influence the mechanism of internalization of TAT peptide.

\subsection{Penetratin}

Penetratin is a 16-amino acid basic cationic CPP, derived from the antennapedia homeodomain, which is capable of inducing the cell uptake of a large variety of molecular cargo [61]. The peptide is translocated across the cell membranes by the third $\alpha$-helix of the homeodomain of antennapedia, known as penetratin. Previous biophysical studies have shown that even though the entry of this peptide requires initial binding to the cell membrane, binding and translocation are differentially affected by the amphiphilic nature and net charge of the peptide. Furthermore, the internalization of penetratin is affected by the lipid composition of the plasma membrane $[62,63]$. 
A group of researchers showed that the presence of negatively-charged lipids in the membrane promote the transfer of penetratin from a hydrophilic to a hydrophobic environment likely via charge neutralization. They showed that the transfer of penetratin can also occur in the absence of the negatively-charged lipid by adding DNA oligonucleotides, by the same mechanism. Their findings further confirmed that charge neutralization and phase transfer represented only the initial step of internalization, while further uptake required the presence of tryptophan at position 6 of the peptide [64]. A previous study showed enhanced accumulation of penetratin-functionalized PEG-(poly lactic acid) (PLA) nanoparticles in rat brain and low uptake by non-specific organs, as compared to the protamine-conjugated nanoparticles [65]. Another group of researchers showed improved transfection efficiency of penetratin-conjugated polymethacrylates as compared to PEI-polymethacrylates and comparable to the gene expression of Lipofectamine ${ }^{\circledR}$ [66]. Conjugation of penetratin with elastin like polypeptides showed maximum reduction in growth and proliferation of human ovarian carcinoma cells (SKOV-3) and HeLa cells [67].

\subsection{Mastoparan}

Mastoparan is a 14-residue peptide from wasp (Vespula lewisii) venom and belongs to a class of peptides that are more amphipathic [68,69]. This peptide has been used in the construction of 21-residue peptide transportan 10 (TP10), which has been widely investigated in the delivery of cargo like proteins into cells [70]. The use of this amphiphilic peptide is restricted due its cytolytic effects [71-73]. Previous reports have indicated the application of mastoparan peptide for mitochondrial delivery, causing increased apoptosis of tumor cells [74,75]. Yamada et al. reported that the peptide caused increased permeability of the mitochondrial membrane, causing the leakage of components from the mitochondrial matrix, eventually leading to apoptosis of tumor cells [76]. Another report showed that the presence of mastoparan peptide, transportan 10 (TP10), significantly increased the transfection efficiency of PEI. Furthermore, a low concentration $(0.6 \mathrm{nM})$ of TP10 conjugates with DNA showed efficient gene expression in HeLa cells and murine fibroblast C3H 10T1/2 cells [77].

Despite the significant advantage of using CPPs for increasing the transport of molecular cargo across the cellular barriers, these highly-efficient carriers have had controversy due the associated toxicity at high concentrations. The delivery of small molecules, vectors and other protein and nucleic acid drugs that are associated with poor brain penetration can be efficiently transported across BBB via adsorptive-mediated transcytosis (AMT). However, the non-specific uptake of the CPP or cationic proteins can result in higher accumulations in blood vessels and peripheral organs. In addition, the toxicity and immunogenicity associated with chemical modifications of proteins can pose a challenge to the practical application of these agents in improving brain delivery. Previous studies have reported membrane toxicity and tissue inflammation using CPPs and cationic albumin nanoparticles [15]. A recent report has indicated that it is non-toxic up to a concentration of $100 \mu \mathrm{M}$; however, after, peptide-bound TAT demonstrated significant and chain length-dependent toxicity irrespective of the sequence of peptide [73]. Another study indicated toxicity associated with a very high dose of the $\mathrm{TAT}_{46-60}$ peptide [78].

\section{Adsorptive-Mediated Transcytosis}

The growing evidence indicating the success of the transport of therapeutic molecules into brain via cationic proteins and cell-penetrating peptides (CPPs) has conveyed significant importance to AMT as the route for the delivery of molecules across BBB. Table 1 illustrates commonly-used CPPs with their features. Despite the variation in length and sequence of amino acids, these peptides share some common features, like their amphipathic nature, net positive charge, theoretical hydrophobicity and helical moment, the ability to interact with lipidic membranes and to adopt a distinct secondary structure upon association with lipids [71]. Adenot et al. have previously reported an increase in the penetration of various chemotherapeutic agents across BBB in in situ and in vitro cell-based models, after conjugation with SynB3 CPP [79]. They reported an increase in brain delivery of doxorubicin 
by a factor of 30, benzylpenicillin by a factor of seven, paclitaxel by a factor of 22, dalargin by a factor of 18 and morphine 6-glucoronide by a factor of 50 without disrupting the function of BBB. Another study reported a significant increase in the uptake of dalargin after conjugation with SynB on intravenous injection into mice [80]. In addition, TAT-conjugated nanoparticles and liposomes have been used for the delivery of therapeutic agents across BBB. Qin et al. reported enhanced penetration of cholestrol-PEG2000-TAT into brain as compared to cholesterol-PEG2000 and conventional cholesterol liposomes [22]. Sharma et al. reported enhanced penetration of CPP-transferrin liposomes into brains of adult Sprague Dawley rats as compared to transferrin-conjugated and conventional plain liposomes [16,17]. A recent study demonstrated significantly $(p<0.001)$ higher accumulation of penetratin-functionalized PEG-PLA nanoparticles in rats as compared to the low molecular weight protamine nanoparticles [65].

Apart from the CPPs, cationic proteins have also been employed to increase the penetration of therapeutic agents across BBB via an adsorptive-mediated mechanism. Poduslo and Curran [81] demonstrated that polyamine modification of proteins (albumin, insulin and $\operatorname{IgG}$ ) dramatically increased their penetration across BBB. The permeability of insulin increased by 1.7-2.0-fold; albumin increased by $54-165$-fold; and IgG increased by 111-349-fold [81]. A previous study compared cationic bovine serum albumin-conjugated PEG-PLA nanoparticles (CBSA-NP) with the native bovine serum albumin-conjugated NP (BSA-NP) and unconjugated nanoparticles (NP) for brain delivery in mice [82]. The results demonstrated that the penetration of CBSA-NP increased by 2.3-fold as compared to NP. Although cationic proteins have shown considerable improvement in the delivery of molecules or delivery vectors across BBB, toxicity or immunogenicity associated with this chemical modification cannot be ruled out [37].

However, one of the difficulties for brain delivery is the poor ability of the formulation to escape from endosomes, which leads to the degradation or accumulation of drug moieties inside brain endothelial cells. This can be overcome by either the use of a $\mathrm{pH}$-sensitive formulation or the use of cationic molecules [83,84]. The mechanism behind the use of the $\mathrm{pH}$-sensitive formulation is the destabilization of the endosomal membrane by fusogenic peptides. The fusogenic peptides undergo conformational changes upon the change in $\mathrm{pH}$, which leads to lipid merging and ultimately endosomal membrane fusion $[85,86]$; while in the case of cationic molecules, the binding of cationic molecules to the endosomal membrane causes thinning of the chain region and creates an internal membrane tension. This tension in the membrane is strong enough to create pores in the endosomal membrane [87]. It has been reported earlier that caveolin-1 protein assists in transcytosis across the endothelial layer $[16,88]$.

Table 1. Features of some naturally-occurring cell-penetrating peptides [14,71,89,90].

\begin{tabular}{cccc}
\hline CPP & Amino Acid Sequence & Net Charge & Cell Lysis Activity \\
\hline pAntp $_{43-68}$ (Penetratin) & RQIKIWFQNRRMKWKK & +8 & No \\
SynB1 & RGGRLSYSRRFSTSTGR & +6 & Yes \\
SBP & MGLGLHLLVAAALQGAWSPKKKRKV & +6 & No \\
SynB3 & RRLSYSRRRF & +6 & - \\
Transportan & GWTLNSAGYLLGKINLKALAALAKKIL & +4 & No \\
FBP & GALFLGWLGAAGSTMGAWSQPKKKRKV & +6 & - \\
TAT $_{48-60}$ & GRKKRRQRRRPPQ & +8 & No \\
\hline & CPP, cell-penetrating peptide. &
\end{tabular}

\section{Receptor-Mediated Transcytosis}

Receptor-mediated transcytosis (RMT) overcomes the limitation of the non-specific uptake by peripheral tissues and blood vessels, thus reducing the side effects associated with AMT. Upregulation of certain receptor types in a diseased condition further enhances the opportunity for active targeting of therapeutic molecules to specific sites and tissues, e.g., transferrin receptors are overexpressed on brain endothelium, and the receptor expression is significantly upregulated in tumor conditions $[46,91]$. 
Cargo molecules, like proteins, peptides and delivery vectors, can be linked with an active targeting ligand and transported across BBB via RMT. Therefore, this approach is also called as the Trojan horse approach [12,92]. Increased understanding of BBB biology and genomics has led to the discovery of a large number of transporters and receptors that can be used for the delivery of molecules across BBB. In general, there are three steps involved in RMT [12,92]:

(1) Endocytosis of the molecules on the luminal (blood) side after binding of the ligand to the targeted receptor.

(2) Movement of the molecules across the endothelial cytoplasm.

(3) Exocytosis of the drug/ligand-attached drug or delivery vector on the abluminal (brain) side.

The second step sometimes leads to endosomal/lysosomal degradation of the drug molecules or cargo. This fate is overcome by using $\mathrm{pH}$-sensitive liposomes or cationic peptides/molecules $[83,84]$. Certain targeting ligands, like diphtheria toxin, have endosomal escaping ability [93]. Advantageously, the lysosomal/endosomal escaping phenomenon is not required for brain delivery and successful transport of small drug molecules, liposomes, nanoparticles and polymeric complexes to brain [93-97].

Transferrin receptors are the most commonly-targeted receptors for the delivery of therapeutic agents to brain. The role of transferrin receptors in BBB transport is given below.

\section{Transferrin Receptors}

Transferrin receptors (TfR) are the widely-studied systems for the RMT of delivery vectors and therapeutic agents across BBB. The receptor is a transmembrane glycoprotein with two subunits of $90 \mathrm{kDa}$ that are linked by a disulfide bridge, and each of these subunits can bind to one molecule of transferrin [98]. In addition to the BBB, this TfR is also expressed on hepatocytes, monocytes, erythrocytes, intestinal cells, epithelial cells of choroid plexus and neurons. TfRs on BBB mediate the transport of iron bound to transferrin into the brain. Nanoparticles, liposomes and therapeutic drug molecules can be conjugated to either transferrin protein or transferrin monoclonal antibody (OX-26). The TfR-targeted monoclonal antibody binds to a different site as compared to transferrin protein and, therefore, is less likely to interfere with the endogenous transferrin in circulation. A recent study reported an improvement in the expression of luciferase gene in C6 glioma cells, primary hippocampal neurons and primary cortical neurons on transfection with transferrin-modified cationic liposomes, as compared to conventional plain liposomes. However, the transfection levels were low with the conjugation of transferrin protein. There low transfection levels with the transferrin-conjugated delivery vector were attributed to the high concentration of transferrin protein in circulation, which competes with the transferrin on the nanoparticle system [99]. Another limitation of using transferrin as a delivery system is that exogenously-supplied transferrin can lead to an overdose of iron transport into brain. In order to avoid the limitations of using transferrin as a delivery system, transferrin receptor-targeted antibodies have been used that bind to a receptor binding site differently compared to the transferrin protein. Different antibodies that have been evaluated include OX26 (anti-rat TfR monoclonal antibody), R17-217 and 8D3 (anti-mouse TfR monoclonal antibody) were all examined. Comparison of the brain uptake of R17-217 and 8D3 revealed a higher uptake of 8D3 (3.1\% injected dose/gram of tissue) as compared to R17-217 (1.7\% injected dose/gram of the tissue) [100]. Ulbrich et al. investigated the distribution and brain targeting properties of human serum albumin nanoparticles conjugated to transferrin protein or transferrin monoclonal antibodies (OX26 or R17-217) for the delivery of loperamide (does not cross BBB) [101]. The results demonstrated significant anti-nociceptive effects with loperamide-loaded human serum albumin HSA nanoparticles after covalent modification with transferrin or antibodies (OX-26 or R17-217). The study also showed enhanced transport of transferrin monoclonal antibody-modified nanoparticles across BBB as compared to the IgG2a antibody or transferrin-modified nanoparticles, thus further confirming the efficacy of monoclonal antibodies over transferrin protein for the delivery of therapeutic agents to brain [101]. A recent report showed a comparison of different targeting ligands in improving the transport of molecules to brain. Five 
different targeting ligands were compared for their ability to target brain, both in vitro and in vivo: transferrin, R17-217 (against TfR), COG 133 (against low density lipoprotein receptor (LDLR) and lipoprotein receptor protein (LRP)), angioprep-2 (against LRP) and cross-reacting material (CRM) 197 (against diphtheria toxin receptor (DTR)). The in vitro results showed that only R17-217 and CRM197 were observed to be associated with human endothelial cells, and only R17-217 showed enhanced brain uptake of liposomes in Balb/c mice at all time points after intravenous injection [102]. The authors studied the distribution of ${ }^{3} \mathrm{H}$-labelled liposomes in brain capillaries using the capillary depletion method and observed that the distribution of R17-217 liposomes was 10-times more than the untargeted liposomes. In addition, R17-217 liposomes were the only ones whose concentration was maintained in the brain over a period of $6 \mathrm{~h}$ and was $0.18 \%$ of the injected dose/gram of tissue after $12 \mathrm{~h}$. The authors also suggested that the higher accumulation of this antibody in comparison to the other groups could be due the higher molecular weight and higher affinity of the antibody to the receptors, leading to a stronger brain targeting ability and a lower rate of elimination [102]. Although the targeting ligand has a significant contribution in improving the delivery of molecules to brain, there are other parameters, like matrix material, particle size, surface properties and the density and conformation of targeting ligand, that also play an important role in brain delivery. A recent study performed by Sharma et al. also showed higher accumulation of transferrin-CPP-modified liposomes in rat brain after $24 \mathrm{~h}$ of intravenous administration [17]. The authors proposed a dual mechanism for improved and targeted delivery of transferrin-modified liposomes (Figure 2). The conjugation of CPP with transferrin liposomes enhanced the penetration of transferrin liposomes into brain by overcoming receptor saturation versus the transferrin-conjugated or untargeted liposomes. Transferrin (Tf) has been evaluated to be an important target for delivery to brain. However, more studies need to be conducted in order to fully understand the function and performance of targeting ligands. The expression of TfR on brain endothelial cells was observed to decrease in brain ischemia [103]. In contrast, the expression was observed to be decreased in the hippocampus of patients with AD, as compared to normal humans $[104,105]$. However, there was a marked increase in the expression of transferrin receptors during brain injury and after intra-cerebral hemorrhage [106].

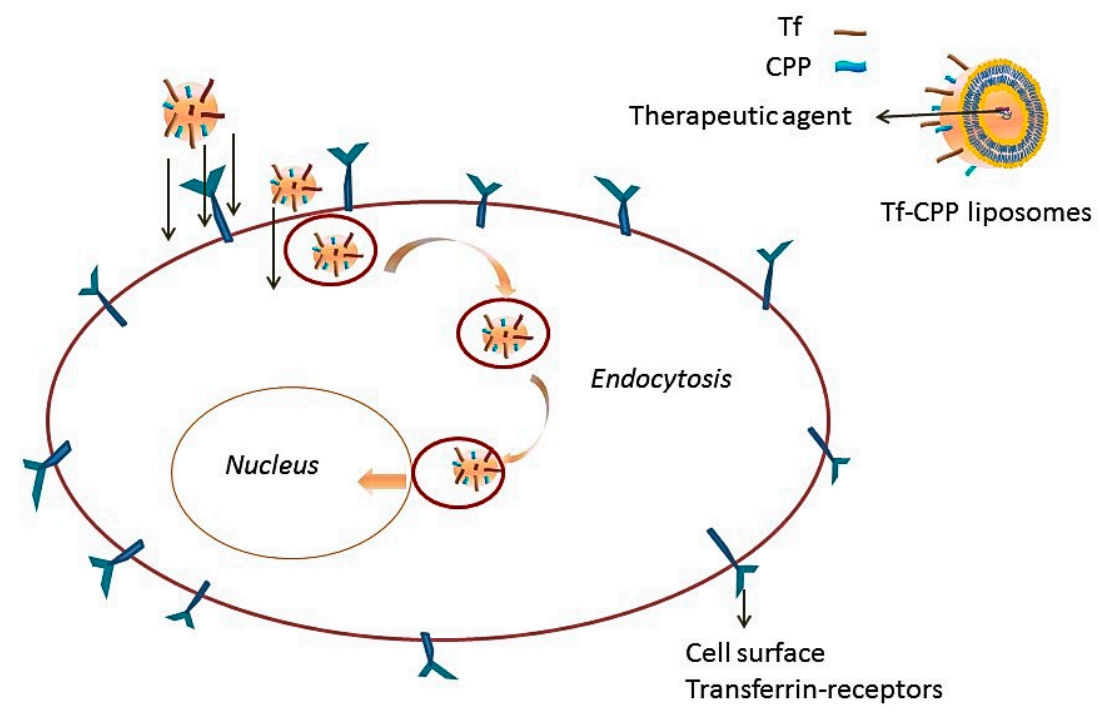

Figure 2. Uptake of liposomes by cells via a dual-mechanism involving receptor targeting and cell penetration.

Several studies have been performed to show the overexpression of TfR on brain endothelial cells $[107,108]$. The TfR is expressed, with 10,000-100,000 molecules per cell commonly found on proliferative brain endothelial (bEnd.3) cell lines in culture $[109,110]$. Such a high density of TfR at BBB will facilitate the greater transport of drug encapsulated and surface-modified with Tf and 
CPP liposomes across the BBB. Additionally, an immunohistochemical evaluation of normal brain tissue and tumor biopsy revealed a differential staining pattern for TfRs on brain endothelial cells of normal and tumor tissue, indicating a higher level of expression in tumor-associated brain endothelial cells [111].

Various in vitro cell culture-based and in situ models have been used in the past to study the transport of molecules across the barrier layer. Despite the simplicity of the construction of the in vitro models, these models are limited by the lack of features, like cell-cell interactions generated in in situ models (e.g., induction, signaling, etc.). Traditionally, the transport of dyes, such as Evans Blue-albumin and fluorescein, measuring the permeability coefficient of the brain endothelium for small radiolabeled molecules, such as sucrose and mannitol, have been used [16,39]. More recently, microelectrode techniques, cable analysis and transendothelial electrical resistance (TEER) instruments have been used to determine the resistance across the endothelial barrier [16].

\section{Nanocarriers for Delivery across BBB}

These are nanoscale carriers for the delivery of therapeutic drugs or other molecules and consist of particles in the size range of 100-1000 $\mu \mathrm{m}$ [112]. These nanocarrier systems include polymeric nanoparticles and lipid-based particles, e.g., liposomes and solid lipid nanoparticles. This emerging class of delivery systems can be easily customized to transport desired therapeutic agents to specific tissues in the body. With the rapid development in polymer chemistry and nanotechnology coupled with an increased understanding of the molecular biology of brain and various receptor systems that can be used to target brain, the development of nanocarriers for delivery to brain has gained the increasing attention of scientists across the world. They can be surface modified for targeting specific receptors, can carry the therapeutic drugs and molecules in sufficient amounts and provide a controlled/targeted release of the therapeutic agent. Ideal nanocarriers should have the following properties for the delivery of drugs/therapeutic agents across BBB [113,114]:

(1) They should be biodegradable, non-toxic and biocompatible.

(2) They should preferably have a size of less than $200 \mathrm{~nm}$.

(3) They should not aggregate/dissociate in blood and should be stable in circulation.

(4) They should be non-immunogenic.

(5) They should have a targeting moiety coupled for delivery across BBB via receptor/adsorptive transcytosis or monocytes and macrophages.

(6) The drug (small molecules, peptides, proteins, nucleic acids) carried should be stable, and the drug release should be tunable.

A large variety of nanocarriers have been developed so far; however, only polymeric nanoparticles and amphiphilic lipids forming liposomes have been extensively exploited for the delivery of therapeutic agents to brain [115]. Table 2 shows various nanocarriers for drug and gene delivery to brain. Several polymeric and liposomal delivery systems for the treatment of brain disorders have reached clinical trials. The University of Regensburg in collaboration with Essex Pharma (Schering-Plough) has successfully completed phase 2 of clinical trials for PEGylated liposomal doxorubicin and prolonged temozolomide in combination with radiotherapy in the treatment of glioblastoma $[7,116]$. Another PEGylated doxorubicin formulation surface modified with glutathione is currently in phase I/II clinical trials in the Antoni van Leeuwenhoek hospital, the Netherlands. Non-amphiphilic colloidal drug carriers, like dendrimers and micro-emulsions, are still at relatively early stages of development. 
Table 2. Examples of drug and gene delivery vectors for transport across BBB.

\begin{tabular}{clc}
\hline Nanoparticles for Brain Delivery & \multicolumn{1}{c}{ Properties } & References \\
\hline Bolaamphiphilic cationic vesicles & $\begin{array}{l}\text { High serum stability, efficient cell uptake and improved } \\
\text { brain targeting }\end{array}$ & {$[117,118]$} \\
\hline $\begin{array}{c}\text { Poly(lactide-co-glycolide) } \\
\text { (PLGA) nanoparticles }\end{array}$ & $\begin{array}{l}\text { Biocompatible, biodegradable, efficient cellular uptake } \\
\text { and delivery of therapeutic agents into cells }\end{array}$ & {$[119,120]$} \\
\hline Angiopep-conjugated nanoparticles & $\begin{array}{l}\text { Internalization by brain capillary endothelial cells, } \\
\text { efficient cell uptake, transport across BBB } \\
\text { and gene expression }\end{array}$ & {$[121,122]$} \\
\hline CPP-modified Tf-liposomes & $\begin{array}{l}\text { Biocompatible, efficient cell uptake, transfection, } \\
\text { transport across BBB in vitro and in vivo }\end{array}$ & {$[16-18]$} \\
\hline RVG peptide-conjugated nanocarriers & $\begin{array}{l}\text { High serum stability, biocompatibility, efficient } \\
\text { transfection in vitro and in vivo }\end{array}$ & {$[123,124]$} \\
\hline Solid lipid nanoparticles & $\begin{array}{l}\text { Biocompatible, efficient cell uptake and drug delivery } \\
\text { in vitro, efficient brain delivery in vivo }\end{array}$ & {$[125-127]$} \\
\hline TAT-liposomes & $\begin{array}{l}\text { Efficient cell uptake, low cytotoxicity, improved brain } \\
\text { targeting and penetration }\end{array}$ & {$[22,128]$} \\
\hline Surfactant-coated nanoparticles & $\begin{array}{l}\text { Efficient brain penetration and } \\
\text { improved therapeutic efficacy }\end{array}$ & {$[129-131]$} \\
\hline Antibody-conjugated nanoparticles & $\begin{array}{l}\text { Significantly enhanced brain delivery, biocompatible, } \\
\text { improved therapeutic efficacy }\end{array}$ & {$[132-134]$} \\
\hline
\end{tabular}

\subsection{Liposomes}

Liposomes are lipid vesicles that have an inner aqueous core surrounded by a phospholipid bilayer. The pulsating development of targeted nanoparticulate systems has allowed efficient delivery of therapeutic agents to brain [51]. Various nano-constructs, like liposomes, dendrimers, lipid-polymeric nanoparticle systems and nanocapsules, have been evaluated in the recent past for the delivery of desired cargo to the target site [135-139]. The versatility of liposomes, their ability to efficiently protect the encapsulated therapeutic agent in circulation and the simplicity of surface engineering provide a substantial advantage to the liposomal delivery vectors over other nanoparticle systems $[140,141]$. These liposomes can be conjugated to proteins for targeting specific receptors. Furthermore, sterically-stabilized liposomes, surface modified with polyethylene glycol (PEG), show a reduction in clearance by the reticuloendothelial system and immunogenic response of the targeting proteins $[142,143]$. Low elimination by the liver and spleen increases the circulation time of liposomes and improves the bioavailability of encapsulated molecules for therapeutic action [144,145].

Functionalization with Ligands for Synergizing the Transport across BBB

Liposomes can be functionalized with one or more ligands for improving the delivery of the encapsulated drug or plasmid to specific cells. Conjugating to multiple ligands can help perform multiple functions, e.g., one vector can facilitate brain tissue targeting, and another ligand can induce cellular uptake and/or intracellular translocation to specific cell compartments, like the nucleus for delivery of pDNA [146].

Conventional liposomes, composed of cholesterol and phospholipids, suffer from high plasma clearance and low transport across BBB. These liposomes can be surface modified with different ligands, like proteins, peptides and antibodies, for targeting specific receptors [147]. Xiang et al. showed increased tumor transport of chlorotoxin-modified PEGylated liposomes loaded with doxorubicin and greater inhibition of the tumor growth as compared to the unmodified liposomes [148]. In another study, Ying et al. [149] evaluated dual-targeting liposomes surface functionalized with $p$-aminophenyl- $\alpha$-D-mannopyranoside and transferrin for crossing the BBB. The dual-modified liposomes showed enhanced transport across in vitro BBB and significantly decreased the C6 glioma tumor volume in rat models [149]. A recent report showed the comparison of five different targeting 
ligands (transferrin, RI7217, COG133, angiopep-2 and CRM197) in improving the brain delivery of liposomes [102]. RI7217 is the antibody targeted to mouse transferrin receptors; COG133 is an apo-E mimetic peptide targeted to the low density lipoprotein receptors (LDLR) on the surface of BBB; angiopep-2 can bind to the LDLR-related protein on the brain endothelial cells; and CRM197 can bind to the diphtheria toxin receptor (DTR). The results indicated that only CRM197 was able to bind to the brain endothelial receptors in vitro, while RI7217 showed maximum uptake into brain in vivo.

\section{Conclusions and Future Prospects}

The multi-ligand nanocarriers bear the potential to serve as safe and efficient non-viral vectors for the transport of desired therapeutic molecules across the BBB.

Specifically, a combination of CPP and receptor-targeting protein (e.g., transferrin) can serve as a promising platform for the design of novel drug and gene delivery vectors. In this review, we have described various challenges involved in the successful transport of therapeutic agents to brain. Transferrin is the most common receptor targeted for delivery of small molecules or proteins across BBB [16]. A combination of the receptor targeting properties of this protein and the efficient cell penetration property of the CPPs has shown significant improvement in brain delivery as compared to only single ligand receptor-targeting agents [17]. This platform can be further manipulated to employ different targeting ligands, like receptor binding amino acid sequences of antibodies and proteins for delivery to desired cells. These specific receptor binding sequences, in combination with short chain CPP sequences, are anticipated to augment the targeting and cellular delivery of lipid-based nanocarriers across different cellular barriers [17]. This approach could therefore be used to target numerous receptors, such as insulin, neuronal nicotinic acetyl choline, vascular endothelial growth factor receptors, etc., for the treatment of diseases, like diabetes, Alzheimer's disease, schizophrenia and tumors.

Acknowledgments: This work was supported by National Institute of General Medical Sciences (NIGMS) of the National Institute of Health Grant \# R15 GM114701 and the Fraternal Order of Eagles.

Author Contributions: Gitanjali Sharma and Jagdish Singh conceived of and designed the review. Sushant Lakkadwala and Amit Modgil wrote the initial draft. All four authors contributed to finalizing the review.

Conflicts of Interest: The authors declare no conflict of interest.

\section{References}

1. Bradbury, M. The Concept of a Blood-Brain Barrier; John Wiley and Sons Ltd.: New York, NY, USA, 1979.

2. Roth, L.J.; Barlow, C.F. Drugs in the brain: Autoradiography and radioassay techniques permit analysis of penetration by labeled drugs. Science 1961, 134, 22-31. [CrossRef] [PubMed]

3. Banks, W.A. Drug delivery to the brain in Alzheimer's disease: Consideration of the blood-brain barrier. Adv. Drug Deliv. Rev. 2012, 64, 629-639. [CrossRef] [PubMed]

4. Davson, H.; Segal, M.B. Blood-Brain Barrier, Physiology of the csf and Blood-Brain Barriers; CRC Press: Boca Raton, FL, USA, 1996; pp. 49-91.

5. Cserr, H.F.; Knopf, P.M. Cervical lymphatics, the blood-brain barrier and the immunoreactivity of the brain: A new view. Immunol. Today 1992, 13, 507-512. [CrossRef]

6. Knopf, P.M.; Cserr, H.F.; Nolan, S.C.; Wu, T.Y.; Harling-Berg, C.J. Physiology and immunology of lymphatic drainage of interstitial and cerebrospinal fluid from the brain. Neuropathol. Appl. Neurobiol. 1995, 21, 175-180. [CrossRef] [PubMed]

7. Chen, Y.; Liu, L. Modern methods for delivery of drugs across the blood-brain barrier. Adv. Drug Deliv. Rev. 2012, 64, 640-665. [CrossRef] [PubMed]

8. Johanson, C.E.; Duncan, J.A., 3rd; Klinge, P.M.; Brinker, T.; Stopa, E.G.; Silverberg, G.D. Multiplicity of cerebrospinal fluid functions: New challenges in health and disease. Cerebrospinal Fluid Res. 2008, 5, 441-450. [CrossRef] [PubMed] 
9. Townsend, S.A.; Evrony, G.D.; Gu, F.X.; Schulz, M.P.; Brown, R.H., Jr.; Langer, R. Tetanus toxin c fragment-conjugated nanoparticles for targeted drug delivery to neurons. Biomaterials 2007, 28, 5176-5184. [CrossRef] [PubMed]

10. Rip, J.; Schenk, G.J.; de Boer, A.G. Differential receptor-mediated drug targeting to the diseased brain. Expert Opin. Drug Deliv. 2009, 6, 227-237. [CrossRef] [PubMed]

11. Pathan, S.A.; Iqbal, Z.; Zaidi, S.M.; Talegaonkar, S.; Vohra, D.; Jain, G.K.; Azeem, A.; Jain, N.; Lalani, J.R.; Khar, R.K.; et al. CNS drug delivery systems: Novel approaches. Recent Pat. Drug Deliv. Formul. 2009, 3, 71-89. [CrossRef] [PubMed]

12. Pardridge, W.M. Blood-brain barrier drug targeting: The future of brain drug development. Mol. Interv. 2003, 3, 90-105, 151. [CrossRef] [PubMed]

13. Hawkins, B.T.; Egleton, R.D. Pathophysiology of the blood-brain barrier: Animal models and methods. Curr. Top. Dev. Biol. 2008, 80, 277-309. [PubMed]

14. Rousselle, C.; Clair, P.; Lefauconnier, J.M.; Kaczorek, M.; Scherrmann, J.M.; Temsamani, J. New advances in the transport of doxorubicin through the blood-brain barrier by a peptide vector-mediated strategy. Mol. Pharmacol. 2000, 57, 679-686. [PubMed]

15. Drin, G.; Cottin, S.; Blanc, E.; Rees, A.R.; Temsamani, J. Studies on the internalization mechanism of cationic cell-penetrating peptides. J. Biol. Chem. 2003, 278, 31192-31201. [CrossRef] [PubMed]

16. Sharma, G.; Modgil, A.; Sun, C.; Singh, J. Grafting of cell-penetrating peptide to receptor-targeted liposomes improves their transfection efficiency and transport across blood-brain barrier model. J. Pharm. Sci. 2012, 101, 2468-2478. [CrossRef] [PubMed]

17. Sharma, G.; Modgil, A.; Layek, B.; Arora, K.; Sun, C.; Law, B.; Singh, J. Cell penetrating peptide tethered bi-ligand liposomes for delivery to brain in vivo: Biodistribution and transfection. J. Control. Release 2013, 167, 1-10. [CrossRef] [PubMed]

18. Sharma, G.; Modgil, A.; Zhong, T.; Sun, C.; Singh, J. Influence of short-chain cell-penetrating peptides on transport of doxorubicin encapsulating receptor-targeted liposomes across brain endothelial barrier. Pharm. Res. 2014, 31, 1194-1209. [CrossRef] [PubMed]

19. Serwer, L.P.; James, C.D. Challenges in drug delivery to tumors of the central nervous system: An overview of pharmacological and surgical considerations. Adv. Drug Deliv. Rev. 2012, 64, 590-597. [CrossRef] [PubMed]

20. Scherrmann, J.M. Drug delivery to brain via the blood-brain barrier. Vasc. Pharmacol. 2002, 38, 349-354. [CrossRef]

21. Kohane, D.S.; Plesnila, N.; Thomas, S.S.; Le, D.; Langer, R.; Moskowitz, M.A. Lipid-sugar particles for intracranial drug delivery: Safety and biocompatibility. Brain Res. 2002, 946, 206-213. [CrossRef]

22. Qin, Y.; Chen, H.; Yuan, W.; Kuai, R.; Zhang, Q.; Xie, F.; Zhang, L.; Zhang, Z.; Liu, J.; He, Q. Liposome formulated with TAT-modified cholesterol for enhancing the brain delivery. Int. J. Pharm. 2011, 419, 85-95. [CrossRef] [PubMed]

23. Stewart, P. Endothelial vesicles in the blood-brain barrier: Are they related to permeability? Cell. Mol. Neurobiol. 2000, 20, 149-163. [CrossRef] [PubMed]

24. Abbott, N.J. Dynamics of CNS barriers: Evolution, differentiation, and modulation. Cell. Mol. Neurobiol. 2005, 25, 5-23. [CrossRef] [PubMed]

25. Oldendorf, W.H.; Cornford, M.E.; Brown, W.J. The large apparent work capability of the blood-brain barrier: A study of the mitochondrial content of capillary endothelial cells in brain and other tissues of the rat. Ann. Neurol. 1977, 1, 409-417. [CrossRef] [PubMed]

26. Abbott, N.J.; Ronnback, L.; Hansson, E. Astrocyte-endothelial interactions at the blood-brain barrier. Nat. Rev. Neurosci. 2006, 7, 41-53. [CrossRef] [PubMed]

27. Ramsauer, M.; Kunz, J.; Krause, D.; Dermietzel, R. Regulation of a blood-brain barrier-specific enzyme expressed by cerebral pericytes (pericytic aminopeptidase N/pAPN) under cell culture conditions. J. Cereb. Blood Flow Metab. 1998, 18, 1270-1281. [CrossRef] [PubMed]

28. Ramsauer, M.; Krause, D.; Dermietzel, R. Angiogenesis of the blood-brain barrier in vitro and the function of cerebral pericytes. FASEB J. 2002, 16, 1274-1276. [CrossRef] [PubMed]

29. Dohgu, S.; Takata, F.; Yamauchi, A.; Nakagawa, S.; Egawa, T.; Naito, M.; Tsuruo, T.; Sawada, Y.; Niwa, M.; Kataoka, Y. Brain pericytes contribute to the induction and up-regulation of blood-brain barrier functions through transforming growth factor- $\beta$ production. Brain Res. 2005, 1038, 208-215. [CrossRef] [PubMed] 
30. Wekerle, H. Immune protection of the brain-Efficient and delicate. J. Infect. Dis. 2002, 186, S140-S144. [CrossRef] [PubMed]

31. Daneman, R.; Rescigno, M. The gut immune barrier and the blood-brain barrier: Are they so different? Immunity 2009, 31, 722-735. [CrossRef] [PubMed]

32. Williams, K.; Alvarez, X.; Lackner, A.A. Central nervous system perivascular cells are immunoregulatory cells that connect the CNS with the peripheral immune system. Glia 2001, 36, 156-164. [CrossRef] [PubMed]

33. Streit, W.J.; Conde, J.R.; Fendrick, S.E.; Flanary, B.E.; Mariani, C.L. Role of microglia in the central nervous system's immune response. Neurol. Res. 2005, 27, 685-691. [PubMed]

34. Levin, V.A. Relationship of octanol/water partition coefficient and molecular weight to rat brain capillary permeability. J. Med. Chem. 1980, 23, 682-684. [CrossRef] [PubMed]

35. Pardridge, W.; Kang, Y.-S.; Buciak, J.; Yang, J. Human insulin receptor monoclonal antibody undergoes high affinity binding to human brain capillaries in vitro and rapid transcytosis through the blood-brain barrier in vivo in the primate. Pharm. Res. 1995, 12, 807-816. [CrossRef] [PubMed]

36. Terasaki, T.; Ohtsuki, S.; Hori, S.; Takanaga, H.; Nakashima, E.; Hosoya, K. New approaches to in vitro models of blood-brain barrier drug transport. Drug Discov. Today 2003, 8, 944-954. [CrossRef]

37. Roney, C.; Kulkarni, P.; Arora, V.; Antich, P.; Bonte, F.; Wu, A.; Mallikarjuana, N.N.; Manohar, S.; Liang, H.F.; Kulkarni, A.R.; et al. Targeted nanoparticles for drug delivery through the blood-brain barrier for Alzheimer's disease. J. Control. Release 2005, 108, 193-214. [CrossRef] [PubMed]

38. Foust, K.D.; Nurre, E.; Montgomery, C.L.; Hernandez, A.; Chan, C.M.; Kaspar, B.K. Intravascular AAV9 preferentially targets neonatal neurons and adult astrocytes. Nat. Biotechnol. 2009, 27, 59-65. [CrossRef] [PubMed]

39. Abbott, N.J. Inflammatory mediators and modulation of blood-brain barrier permeability. Cell Mol. Neurobiol. 2000, 20, 131-147. [CrossRef] [PubMed]

40. Lopez-Ramirez, M.A.; Wu, D.; Pryce, G.; Simpson, J.E.; Reijerkerk, A.; King-Robson, J.; Kay, O.; de Vries, H.E.; Hirst, M.C.; Sharrack, B.; et al. MicroRNA-155 negatively affects blood-brain barrier function during neuroinflammation. FASEB J. 2014, 28, 2551-2565. [CrossRef] [PubMed]

41. Schmidt, N.; Mishra, A.; Lai, G.H.; Wong, G.C. Arginine-rich cell-penetrating peptides. FEBS Lett. 2010, 584, 1806-1813. [CrossRef] [PubMed]

42. Snyder, E.L.; Dowdy, S.F. Cell penetrating peptides in drug delivery. Pharm. Res. 2004, 21, 389-393. [CrossRef] [PubMed]

43. Lewin, M.; Carlesso, N.; Tung, C.H.; Tang, X.W.; Cory, D.; Scadden, D.T.; Weissleder, R. Tat peptide-derivatized magnetic nanoparticles allow in vivo tracking and recovery of progenitor cells. Nat. Biotechnol. 2000, 18, 410-414. [PubMed]

44. Torchilin, V.P.; Rammohan, R.; Weissig, V.; Levchenko, T.S. TAT peptide on the surface of liposomes affords their efficient intracellular delivery even at low temperature and in the presence of metabolic inhibitors. Proc. Natl. Acad. Sci. USA 2001, 98, 8786-8791. [CrossRef] [PubMed]

45. Torchilin, V.P.; Levchenko, T.S.; Rammohan, R.; Volodina, N.; Papahadjopoulos-Sternberg, B.; D'Souza, G.G. Cell transfection in vitro and in vivo with nontoxic TAT peptide-liposome-DNA complexes. Proc. Natl. Acad. Sci. USA 2003, 100, 1972-1977. [CrossRef] [PubMed]

46. Huwyler, J.; Wu, D.; Pardridge, W.M. Brain drug delivery of small molecules using immunoliposomes. Proc. Natl. Acad. Sci. USA 1996, 93, 14164-14169. [CrossRef] [PubMed]

47. Yamano, S.; Dai, J.; Hanatani, S.; Haku, K.; Yamanaka, T.; Ishioka, M.; Takayama, T.; Yuvienco, C.; Khapli, S.; Moursi, A.M.; et al. Long-term efficient gene delivery using polyethylenimine with modified TAT peptide. Biomaterials 2014, 35, 1705-1715. [CrossRef] [PubMed]

48. Trabulo, S.; Cardoso, A.L.; Mano, M.; de Lima, M.C.P. Cell-penetrating peptides-Mechanisms of cellular uptake and generation of delivery systems. Pharmaceuticals 2010, 3, 961. [CrossRef]

49. Li, J.; Zhang, X.; Wang, M.; Li, X.; Mu, H.; Wang, A.; Liu, W.; Li, Y.; Wu, Z.; Sun, K. Synthesis of a bi-functional dendrimer-based nanovehicle co-modified with RGDyC and TAT peptides for neovascular targeting and penetration. Int. J. Pharm. 2016, 501, 112-123. [CrossRef] [PubMed]

50. Kibria, G.; Hatakeyama, H.; Ohga, N.; Hida, K.; Harashima, H. Dual-ligand modification of pegylated liposomes shows better cell selectivity and efficient gene delivery. J. Control. Release 2011, 153, 141-148. [CrossRef] [PubMed] 
51. Cheng, J.; Teply, B.A.; Sherifi, I.; Sung, J.; Luther, G.; Gu, F.X.; Levy-Nissenbaum, E.; Radovic-Moreno, A.F.; Langer, R.; Farokhzad, O.C. Formulation of functionalized PLGA-PEG nanoparticles for in vivo targeted drug delivery. Biomaterials 2007, 28, 869-876. [CrossRef] [PubMed]

52. Zheng, C.; Ma, C.; Bai, E.; Yang, K.; Xu, R. Transferrin and cell-penetrating peptide dual-functioned liposome for targeted drug delivery to glioma. Int. J. Clin. Exp. Med. 2015, 8, 1658-1668. [PubMed]

53. Opanasopit, P.; Tragulpakseerojn, J.; Apirakaramwong, A.; Ngawhirunpat, T.; Rojanarata, T.; Ruktanonchai, U. The development of poly-L-arginine-coated liposomes for gene delivery. Int. J. Nanomed. 2011, 6, 2245-2252. [CrossRef] [PubMed]

54. Disalvo, E.A.; Bouchet, A.M. Electrophoretic mobility and $\zeta$ potential of liposomes due to arginine and polyarginine adsorption. Colloids Surf. A 2014, 440, 170-174. [CrossRef]

55. Zhang, C.; Tang, N.; Liu, X.; Liang, W.; Xu, W.; Torchilin, V.P. siRNA-containing liposomes modified with polyarginine effectively silence the targeted gene. J. Control. Release 2006, 112, 229-239. [CrossRef] [PubMed]

56. Mäe, M.; Myrberg, H.; El-Andaloussi, S.; Langel, Ü. Design of a tumor homing cell-penetrating peptide for drug delivery. Int. J. Pept. Res. Ther. 2009, 15, 11-15. [CrossRef]

57. Ziegler, A.; Nervi, P.; Durrenberger, M.; Seelig, J. The cationic cell-penetrating peptide CPP(TAT) derived from the HIV-1 protein TAT is rapidly transported into living fibroblasts: Optical, biophysical, and metabolic evidence. Biochemistry 2005, 44, 138-148. [CrossRef] [PubMed]

58. Rudolph, C.; Schillinger, U.; Ortiz, A.; Tabatt, K.; Plank, C.; Muller, R.H.; Rosenecker, J. Application of novel solid lipid nanoparticle (SLN)-gene vector formulations based on a dimeric HIV-1 TAT-peptide in vitro and in vivo. Pharm. Res. 2004, 21, 1662-1669. [CrossRef] [PubMed]

59. Suk, J.S.; Suh, J.; Choy, K.; Lai, S.K.; Fu, J.; Hanes, J. Gene delivery to differentiated neurotypic cells with RGD and HIV TAT peptide functionalized polymeric nanoparticles. Biomaterials 2006, 27, 5143-5150. [CrossRef] [PubMed]

60. Gupta, B.; Levchenko, T.S.; Torchilin, V.P. TAT peptide-modified liposomes provide enhanced gene delivery to intracranial human brain tumor xenografts in nude mice. Oncol. Res. 2007, 16, 351-359. [PubMed]

61. Barany-Wallje, E.; Keller, S.; Serowy, S.; Geibel, S.; Pohl, P.; Bienert, M.; Dathe, M. A critical reassessment of penetratin translocation across lipid membranes. Biophys. J. 2005, 89, 2513-2521. [CrossRef] [PubMed]

62. Drin, G.; Mazel, M.; Clair, P.; Mathieu, D.; Kaczorek, M.; Temsamani, J. Physico-chemical requirements for cellular uptake of pantp peptide. Role of lipid-binding affinity. Eur. J. Biochem. 2001, 268, 1304-1314. [CrossRef] [PubMed]

63. Scheller, A.; Wiesner, B.; Melzig, M.; Bienert, M.; Oehlke, J. Evidence for an amphipathicity independent cellular uptake of amphipathic cell-penetrating peptides. Eur. J. Biochem. 2000, 267, 6043-6050. [CrossRef] [PubMed]

64. Dom, G.; Shaw-Jackson, C.; Matis, C.; Bouffioux, O.; Picard, J.J.; Prochiantz, A.; Mingeot-Leclercq, M.P.; Brasseur, R.; Rezsohazy, R. Cellular uptake of antennapedia penetratin peptides is a two-step process in which phase transfer precedes a tryptophan-dependent translocation. Nucleic Acids Res. 2003, 31, 556-561. [CrossRef] [PubMed]

65. Xia, H.; Gao, X.; Gu, G.; Liu, Z.; Hu, Q.; Tu, Y.; Song, Q.; Yao, L.; Pang, Z.; Jiang, X.; et al. Penetratin-functionalized PEG-PLA nanoparticles for brain drug delivery. Int. J. Pharm. 2012, 436, 840-850. [CrossRef] [PubMed]

66. Christiaens, B.; Dubruel, P.; Grooten, J.; Goethals, M.; Vandekerckhove, J.; Schacht, E.; Rosseneu, M. Enhancement of polymethacrylate-mediated gene delivery by penetratin. Eur. J. Pharm. Sci. 2005, 24, 525-537. [CrossRef] [PubMed]

67. Massodi, I.; Bidwell, G.L., 3rd; Raucher, D. Evaluation of cell penetrating peptides fused to elastin-like polypeptide for drug delivery. J. Control. Release 2005, 108, 396-408. [CrossRef] [PubMed]

68. Yandek, L.E.; Pokorny, A.; Floren, A.; Knoelke, K.; Langel, U.; Almeida, P.F. Mechanism of the cell-penetrating peptide transportan 10 permeation of lipid bilayers. Biophys. J. 2007, 92, 2434-2444. [CrossRef] [PubMed]

69. Hallbrink, M.; Floren, A.; Elmquist, A.; Pooga, M.; Bartfai, T.; Langel, U. Cargo delivery kinetics of cell-penetrating peptides. Biochim. Biophys. Acta 2001, 1515, 101-109. [CrossRef]

70. Pooga, M.; Kut, C.; Kihlmark, M.; Hallbrink, M.; Fernaeus, S.; Raid, R.; Land, T.; Hallberg, E.; Bartfai, T.; Langel, U. Cellular translocation of proteins by transportan. FASEB J. 2001, 15, 1451-1453. [CrossRef] [PubMed] 
71. Deshayes, S.; Morris, M.C.; Divita, G.; Heitz, F. Cell-penetrating peptides: Tools for intracellular delivery of therapeutics. Cell Mol. Life Sci. 2005, 62, 1839-1849. [CrossRef] [PubMed]

72. Saar, K.; Lindgren, M.; Hansen, M.; Eiriksdottir, E.; Jiang, Y.; Rosenthal-Aizman, K.; Sassian, M.; Langel, U. Cell-penetrating peptides: A comparative membrane toxicity study. Anal. Biochem. 2005, 345, 55-65. [CrossRef] [PubMed]

73. Cardozo, A.K.; Buchillier, V.; Mathieu, M.; Chen, J.; Ortis, F.; Ladriere, L.; Allaman-Pillet, N.; Poirot, O.; Kellenberger, S.; Beckmann, J.S.; et al. Cell-permeable peptides induce dose- and length-dependent cytotoxic effects. Biochim. Biophys. Acta 2007, 1768, 2222-2234. [CrossRef] [PubMed]

74. Pfeiffer, D.R.; Gudz, T.I.; Novgorodov, S.A.; Erdahl, W.L. The peptide mastoparan is a potent facilitator of the mitochondrial permeability transition. J. Biol. Chem. 1995, 270, 4923-4932. [CrossRef] [PubMed]

75. Hirai, Y.; Kuwada, M.; Yasuhara, T.; Yoshida, H.; Nakajima, T. A new mast cell degranulating peptide homologous to mastoparan in the venom of japanese hornet (Vespa xanthoptera). Chem. Pharm. Bull 1979, 27, 1945-1946. [CrossRef] [PubMed]

76. Yamada, Y.; Harashima, H. Mitochondrial drug delivery systems for macromolecule and their therapeutic application to mitochondrial diseases. Adv. Drug Deliv. Rev. 2008, 60, 1439-1462. [CrossRef] [PubMed]

77. Kilk, K.; El-Andaloussi, S.; Jarver, P.; Meikas, A.; Valkna, A.; Bartfai, T.; Kogerman, P.; Metsis, M.; Langel, U. Evaluation of transportan 10 in PEI mediated plasmid delivery assay. J. Control. Release 2005, 103, 511-523. [CrossRef] [PubMed]

78. Sabatier, J.M.; Vives, E.; Mabrouk, K.; Benjouad, A.; Rochat, H.; Duval, A.; Hue, B.; Bahraoui, E. Evidence for neurotoxic activity of TAT from human immunodeficiency virus type 1. J. Virol. 1991, 65, 961-967. [PubMed]

79. Adenot, M.; Merida, P.; Lahana, R. Applications of a blood-brain barrier technology platform to predict CNS penetration of various chemotherapeutic agents. 2. Cationic peptide vectors for brain delivery. Chemotherapy 2007, 53, 73-76. [CrossRef] [PubMed]

80. Rousselle, C.; Clair, P.; Smirnova, M.; Kolesnikov, Y.; Pasternak, G.W.; Gac-Breton, S.; Rees, A.R.; Scherrmann, J.M.; Temsamani, J. Improved brain uptake and pharmacological activity of dalargin using a peptide-vector-mediated strategy. J. Pharmacol. Exp. Ther. 2003, 306, 371-376. [CrossRef] [PubMed]

81. Poduslo, J.F.; Curran, G.L. Polyamine modification increases the permeability of proteins at the blood-nerve and blood-brain barriers. J. Neurochem. 1996, 66, 1599-1609. [CrossRef] [PubMed]

82. Lu, W.; Wan, J.; Zhang, Q.; She, Z.; Jiang, X. Aclarubicin-loaded cationic albumin-conjugated PEGylated nanoparticle for glioma chemotherapy in rats. Int. J. Cancer 2007, 120, 420-431. [CrossRef] [PubMed]

83. Bartsch, M.; Weeke-Klimp, A.H.; Meijer, D.K.; Scherphof, G.L.; Kamps, J.A. Cell-specific targeting of lipid-based carriers for odn and DNA. J. Liposome Res. 2005, 15, 59-92. [CrossRef] [PubMed]

84. Shir, A.; Ogris, M.; Wagner, E.; Levitzki, A. Egf receptor-targeted synthetic double-stranded rna eliminates glioblastoma, breast cancer, and adenocarcinoma tumors in mice. PLoS Med. 2006, 3, e6.

85. Marsh, M.; Helenius, A. Virus entry into animal cells. Adv. Virus Res. 1989, 36, 107-151. [PubMed]

86. Horth, M.; Lambrecht, B.; Khim, M.C.; Bex, F.; Thiriart, C.; Ruysschaert, J.M.; Burny, A.; Brasseur, R. Theoretical and functional analysis of the siv fusion peptide. EMBO J. 1991, 10, 2747-2755. [PubMed]

87. Varkouhi, A.K.; Scholte, M.; Storm, G.; Haisma, H.J. Endosomal escape pathways for delivery of biologicals. J. Control. Release 2011, 151, 220-228. [CrossRef] [PubMed]

88. Frank, P.G.; Woodman, S.E.; Park, D.S.; Lisanti, M.P. Caveolin, caveolae, and endothelial cell function. Arterioscler. Thromb. Vasc. Biol. 2003, 23, 729-736. [CrossRef] [PubMed]

89. Batrakova, E.V.; Li, S.; Alakhov, V.Y.; Miller, D.W.; Kabanov, A.V. Optimal structure requirements for pluronic block copolymers in modifying p-glycoprotein drug efflux transporter activity in bovine brain microvessel endothelial cells. J. Pharmacol. Exp. Ther. 2003, 304, 845-854. [CrossRef] [PubMed]

90. Zorko, M.; Langel, U. Cell-penetrating peptides: Mechanism and kinetics of cargo delivery. Adv. Drug Deliv. Rev. 2005, 57, 529-545. [CrossRef] [PubMed]

91. Oba, M.; Fukushima, S.; Kanayama, N.; Aoyagi, K.; Nishiyama, N.; Koyama, H.; Kataoka, K. Cyclic RGD peptide-conjugated polyplex micelles as a targetable gene delivery system directed to cells possessing $\alpha \mathrm{v} \beta 3$ and $\alpha \mathrm{v} \beta 5$ integrins. Bioconjug. Chem. 2007, 18, 1415-1423. [CrossRef] [PubMed]

92. Pardridge, W.M. Drug and gene targeting to the brain with molecular trojan horses. Nat. Rev. Drug Discov. 2002, 1, 131-139. [CrossRef] [PubMed]

93. De Boer, A.G.; Gaillard, P.J. Drug targeting to the brain. Annu. Rev. Pharmacol. Toxicol. 2007, 47, $323-355$. [CrossRef] [PubMed] 
94. Gabathuler, R. Approaches to transport therapeutic drugs across the blood-brain barrier to treat brain diseases. Neurobiol. Dis. 2010, 37, 48-57. [CrossRef] [PubMed]

95. Johnsen, K.B.; Moos, T. Revisiting nanoparticle technology for blood-brain barrier transport: Unfolding at the endothelial gate improves the fate of transferrin receptor-targeted liposomes. J. Control. Release 2016, 222, 32-46. [CrossRef] [PubMed]

96. Gregori, M.; Orlando, A.; Re, F.; Sesana, S.; Nardo, L.; Salerno, D.; Mantegazza, F.; Salvati, E.; Zito, A.; Malavasi, F.; et al. Novel antitransferrin receptor antibodies improve the blood-brain barrier crossing efficacy of immunoliposomes. J. Pharm. Sci. 2016, 105, 276-283. [CrossRef] [PubMed]

97. Chen, Z.-L.; Huang, M.; Wang, X.-R.; Fu, J.; Han, M.; Shen, Y.-Q.; Xia, Z.; Gao, J.-Q. Transferrin-modified liposome promotes $\alpha$-mangostin to penetrate the blood-brain barrier. Nanomed. Nanotechnol. Biol. Med. 2016, 12, 421-430. [CrossRef] [PubMed]

98. Moos, T.; Morgan, E.H. Transferrin and transferrin receptor function in brain barrier systems. Cell. Mol. Neurobiol. 2000, 20, 77-95. [CrossRef] [PubMed]

99. Da Cruz, M.T.; Simoes, S.; de Lima, M.C. Improving lipoplex-mediated gene transfer into C6 glioma cells and primary neurons. Exp. Neurol. 2004, 187, 65-75. [CrossRef] [PubMed]

100. Lee, H.J.; Engelhardt, B.; Lesley, J.; Bickel, U.; Pardridge, W.M. Targeting rat anti-mouse transferrin receptor monoclonal antibodies through blood-brain barrier in mouse. J. Pharmacol. Exp. Ther. 2000, 292, 1048-1052. [PubMed]

101. Ulbrich, K.; Hekmatara, T.; Herbert, E.; Kreuter, J. Transferrin- and transferrin-receptor-antibody-modified nanoparticles enable drug delivery across the blood-brain barrier (BBB). Eur. J. Pharm. Biopharm. 2009, 71, 251-256. [CrossRef] [PubMed]

102. Van Rooy, I.; Mastrobattista, E.; Storm, G.; Hennink, W.E.; Schiffelers, R.M. Comparison of five different targeting ligands to enhance accumulation of liposomes into the brain. J. Control. Release 2011, 150, 30-36. [CrossRef] [PubMed]

103. Moos, T.; Morgan, E.H. The metabolism of neuronal iron and its pathogenic role in neurological disease: Review. Ann. N. Y. Acad. Sci. 2004, 1012, 14-26. [CrossRef] [PubMed]

104. Morris, C.M.; Candy, J.M.; Kerwin, J.M.; Edwardson, J.A. Transferrin receptors in the normal human hippocampus and in Alzheimer's disease. Neuropathol. Appl. Neurobiol. 1994, 20, 473-477. [CrossRef] [PubMed]

105. Kalaria, R.N.; Sromek, S.M.; Grahovac, I.; Harik, S.I. Transferrin receptors of rat and human brain and cerebral microvessels and their status in Alzheimer's disease. Brain Res. 1992, 585, 87-93. [CrossRef]

106. Wu, J.; Hua, Y.; Keep, R.F.; Nakamura, T.; Hoff, J.T.; Xi, G. Iron and iron-handling proteins in the brain after intracerebral hemorrhage. Stroke 2003, 34, 2964-2969. [CrossRef] [PubMed]

107. Moos, T.; Morgan, E.H. Restricted transport of anti-transferrin receptor antibody (OX26) through the blood-brain barrier in the rat. J. Neurochem. 2001, 79, 119-129. [CrossRef] [PubMed]

108. Bickel, U.; Yoshikawa, T.; Pardridge, W.M. Delivery of peptides and proteins through the blood-brain barrier. Adv. Drug Deliv. Rev. 2001, 46, 247-279. [CrossRef]

109. Qian, Z.M.; Li, H.; Sun, H.; Ho, K. Targeted drug delivery via the transferrin receptor-mediated endocytosis pathway. Pharmacol. Rev. 2002, 54, 561-587. [CrossRef] [PubMed]

110. Inoue, T.; Cavanaugh, P.G.; Steck, P.A.; Brunner, N.; Nicolson, G.L. Differences in transferrin response and numbers of transferrin receptors in rat and human mammary carcinoma lines of different metastatic potentials. J. Cell. Physiol. 1993, 156, 212-217. [CrossRef] [PubMed]

111. Recht, L.; Torres, C.O.; Smith, T.W.; Raso, V.; Griffin, T.W. Transferrin receptor in normal and neoplastic brain tissue: Implications for brain-tumor immunotherapy. J. Neurosurg. 1990, 72, 941-945. [CrossRef] [PubMed]

112. Kreuter, J. Application of nanoparticles for the delivery of drugs to the brain. Int. Congr. Ser. 2005, 1277, 85-94. [CrossRef]

113. Koo, Y.E.; Reddy, G.R.; Bhojani, M.; Schneider, R.; Philbert, M.A.; Rehemtulla, A.; Ross, B.D.; Kopelman, R. Brain cancer diagnosis and therapy with nanoplatforms. Adv. Drug Deliv. Rev. 2006, 58, 1556-1577. [CrossRef] [PubMed]

114. Bhaskar, S.; Tian, F.; Stoeger, T.; Kreyling, W.; de la Fuente, J.M.; Grazú, V.; Borm, P.; Estrada, G.; Ntziachristos, V.; Razansky, D. Multifunctional nanocarriers for diagnostics, drug delivery and targeted treatment across blood-brain barrier: Perspectives on tracking and neuroimaging. Part. Fibre Toxicol. 2010, 7 , 3. [CrossRef] [PubMed] 
115. Garcia-Garcia, E.; Andrieux, K.; Gil, S.; Couvreur, P. Colloidal carriers and blood-brain barrier (BBB) translocation: A way to deliver drugs to the brain? Int. J. Pharm. 2005, 298, 274-292. [CrossRef] [PubMed]

116. Beier, C.P.; Schmid, C.; Gorlia, T.; Kleinletzenberger, C.; Beier, D.; Grauer, O.; Steinbrecher, A.; Hirschmann, B.; Brawanski, A.; Dietmaier, C.; et al. RNOP-09: PEGylated liposomal doxorubicine and prolonged temozolomide in addition to radiotherapy in newly diagnosed glioblastoma-A phase II study. BMC Cancer 2009, 9. [CrossRef] [PubMed]

117. Dakwar, G.R.; Hammad, I.A.; Popov, M.; Linder, C.; Grinberg, S.; Heldman, E.; Stepensky, D. Delivery of proteins to the brain by bolaamphiphilic nano-sized vesicles. J. Control. Release 2012, 160, 315-321. [CrossRef] [PubMed]

118. Philosof-Mazor, L.; Dakwar, G.R.; Popov, M.; Kolusheva, S.; Shames, A.; Linder, C.; Greenberg, S.; Heldman, E.; Stepensky, D.; Jelinek, R. Bolaamphiphilic vesicles encapsulating iron oxide nanoparticles: New vehicles for magnetically targeted drug delivery. Int. J. Pharm. 2013, 450, 241-249. [CrossRef] [PubMed]

119. Jalali, N.; Moztarzadeh, F.; Mozafari, M.; Asgari, S.; Motevalian, M.; Alhosseini, S.N. Surface modification of poly(lactide-co-glycolide) nanoparticles by D- $\alpha$-tocopheryl polyethylene glycol 1000 succinate as potential carrier for the delivery of drugs to the brain. Colloids Surf. A 2011, 392, 335-342. [CrossRef]

120. Seju, U.; Kumar, A.; Sawant, K.K. Development and evaluation of olanzapine-loaded PLGA nanoparticles for nose-to-brain delivery: In vitro and in vivo studies. Acta Biomater. 2011, 7, 4169-4176. [CrossRef] [PubMed]

121. Ke, W.; Shao, K.; Huang, R.; Han, L.; Liu, Y.; Li, J.; Kuang, Y.; Ye, L.; Lou, J.; Jiang, C. Gene delivery targeted to the brain using an angiopep-conjugated polyethyleneglycol-modified polyamidoamine dendrimer. Biomaterials 2009, 30, 6976-6985. [CrossRef] [PubMed]

122. Shao, K.; Huang, R.; Li, J.; Han, L.; Ye, L.; Lou, J.; Jiang, C. Angiopep-2 modified PE-PEG based polymeric micelles for amphotericin B delivery targeted to the brain. J. Control. Release 2010, 147, 118-126. [CrossRef] [PubMed]

123. Kim, J.Y.; Choi, W.I.; Kim, Y.H.; Tae, G. Brain-targeted delivery of protein using chitosan- and RVG peptide-conjugated, pluronic-based nano-carrier. Biomaterials 2013, 34, 1170-1178. [CrossRef] [PubMed]

124. Son, S.; Hwang do, W.; Singha, K.; Jeong, J.H.; Park, T.G.; Lee, D.S.; Kim, W.J. RVG peptide tethered bioreducible polyethylenimine for gene delivery to brain. J. Control. Release 2011, 155, 18-25. [CrossRef] [PubMed]

125. Martins, S.; Tho, I.; Reimold, I.; Fricker, G.; Souto, E.; Ferreira, D.; Brandl, M. Brain delivery of camptothecin by means of solid lipid nanoparticles: Formulation design, in vitro and in vivo studies. Int. J. Pharm. 2012, 439, 49-62. [CrossRef] [PubMed]

126. Venishetty, V.K.; Samala, R.; Komuravelli, R.; Kuncha, M.; Sistla, R.; Diwan, P.V. $\beta$-hydroxybutyric acid grafted solid lipid nanoparticles: A novel strategy to improve drug delivery to brain. Nanomedicine 2013, 9 , 388-397. [CrossRef] [PubMed]

127. Madan, J.; Pandey, R.S.; Jain, V.; Katare, O.P.; Chandra, R.; Katyal, A. Poly(ethylene)-glycol conjugated solid lipid nanoparticles of noscapine improve biological half-life, brain delivery and efficacy in glioblastoma cells. Nanomedicine 2013, 9, 492-503. [CrossRef] [PubMed]

128. Wang, Y.; Su, W.; Li, Q.; Li, C.; Wang, H.; Li, Y.; Cao, Y.; Chang, J.; Zhang, L. Preparation and evaluation of lidocaine hydrochloride-loaded TAT-conjugated polymeric liposomes for transdermal delivery. Int. J. Pharm. 2013, 441, 748-756. [CrossRef] [PubMed]

129. Borchard, G.; Audus, K.L.; Shi, F.; Kreuter, J. Uptake of surfactant-coated poly(methyl methacrylate)-nanoparticles by bovine brain microvessel endothelial cell monolayers. Int. J. Pharm. 1994, 110, 29-35. [CrossRef]

130. Kreuter, J.; Petrov, V.E.; Kharkevich, D.A.; Alyautdin, R.N. Influence of the type of surfactant on the analgesic effects induced by the peptide dalargin after its delivery across the blood-brain barrier using surfactant-coated nanoparticles. J. Control. Release 1997, 49, 81-87. [CrossRef]

131. Wilson, B.; Samanta, M.K.; Santhi, K.; Kumar, K.P.; Paramakrishnan, N.; Suresh, B. Poly(n-butylcyanoacrylate) nanoparticles coated with polysorbate 80 for the targeted delivery of rivastigmine into the brain to treat Alzheimer's disease. Brain Res. 2008, 1200, 159-168. [CrossRef] [PubMed]

132. Pang, Z.; Lu, W.; Gao, H.; Hu, K.; Chen, J.; Zhang, C.; Gao, X.; Jiang, X.; Zhu, C. Preparation and brain delivery property of biodegradable polymersomes conjugated with OX26. J. Control. Release 2008, 128, 120-127. [CrossRef] [PubMed] 
133. Feng, B.; Tomizawa, K.; Michiue, H.; Miyatake, S.; Han, X.J.; Fujimura, A.; Seno, M.; Kirihata, M.; Matsui, H. Delivery of sodium borocaptate to glioma cells using immunoliposome conjugated with anti-EGFR antibodies by ZZ-His. Biomaterials 2009, 30, 1746-1755. [CrossRef] [PubMed]

134. Furrer, E.; Hulmann, V.; Urech, D.M. Intranasal delivery of ESBA105, a TNF- $\alpha$-inhibitory scFv antibody fragment to the brain. J. Neuroimmunol. 2009, 215, 65-72. [CrossRef] [PubMed]

135. Allen, T.M.; Cullis, P.R. Drug delivery systems: Entering the mainstream. Science 2004, 303, 1818-1822. [CrossRef] [PubMed]

136. Carlmark, A.; Hawker, C.; Hult, A.; Malkoch, M. New methodologies in the construction of dendritic materials. Chem. Soc. Rev. 2009, 38, 352-362. [CrossRef] [PubMed]

137. Szoka, F.; Jacobson, K.; Derzko, Z.; Papahadjopoulos, D. Fluorescence studies on the mechanism of liposome-cell interactions in vitro. Biochim. Biophys. Acta 1980, 600, 1-18. [CrossRef]

138. Müller, R.H.; Mäder, K.; Gohla, S. Solid lipid nanoparticles (SLN) for controlled drug delivery-A review of the state of the art. Eur. J. Pharm. Biopharm. 2000, 50, 161-177. [CrossRef]

139. Vauthier, C.; Bouchemal, K. Methods for the preparation and manufacture of polymeric nanoparticles. Pharm. Res. 2009, 26, 1025-1058. [CrossRef] [PubMed]

140. Maeda, H.; Wu, J.; Sawa, T.; Matsumura, Y.; Hori, K. Tumor vascular permeability and the epr effect in macromolecular therapeutics: A review. J. Control. Release 2000, 65, 271-284. [CrossRef]

141. Vasir, J.K.; Reddy, M.K.; Labhasetwar, V.D. Nanosystems in drug targeting: Opportunities and challenges. Curr. Nanosci. 2005, 1, 47-64. [CrossRef]

142. Shek, P.N.; Lopez, N.G.; Heath, T.D. Immune response mediated by liposome-associated protein antigens. IV. Modulation of antibody formation by vesicle-encapsulated methotrexate. Immunology 1986, 57, 153-157. [PubMed]

143. Harasym, T.O.; Bally, M.B.; Tardi, P. Clearance properties of liposomes involving conjugated proteins for targeting. Adv. Drug Deliv. Rev. 1998, 32, 99-118. [CrossRef]

144. Klibanov, A.L.; Maruyama, K.; Torchilin, V.P.; Huang, L. Amphipathic polyethyleneglycols effectively prolong the circulation time of liposomes. FEBS Lett. 1990, 268, 235-237. [CrossRef]

145. Woodle, M.C. Sterically stabilized liposome therapeutics. Adv. Drug Deliv.Rev. 1995, 16, 249-265. [CrossRef]

146. Tan, P.H.; Manunta, M.; Ardjomand, N.; Xue, S.A.; Larkin, D.F.; Haskard, D.O.; Taylor, K.M.; George, A.J. Antibody targeted gene transfer to endothelium. J. Gene Med. 2003, 5, 311-323. [CrossRef] [PubMed]

147. Schnyder, A.; Huwyler, J. Drug transport to brain with targeted liposomes. NeuroRx 2005, 2, 99-107. [CrossRef] [PubMed]

148. Xiang, Y.; Liang, L.; Wang, X.; Wang, J.; Zhang, X.; Zhang, Q. Chloride channel-mediated brain glioma targeting of chlorotoxin-modified doxorubicine-loaded liposomes. J. Control. Release 2011, 152, 402-410. [CrossRef] [PubMed]

149. Ying, X.; Wen, H.; Lu, W.L.; Du, J.; Guo, J.; Tian, W.; Men, Y.; Zhang, Y.; Li, R.J.; Yang, T.Y.; et al. Dual-targeting daunorubicin liposomes improve the therapeutic efficacy of brain glioma in animals. J. Control. Release 2010, 141, 183-192. [CrossRef] [PubMed]

(C) 2016 by the authors; licensee MDPI, Basel, Switzerland. This article is an open access article distributed under the terms and conditions of the Creative Commons Attribution (CC-BY) license (http://creativecommons.org/licenses/by/4.0/). 